\title{
Kontrol Diri terhadap Agresivitas pada Remaja Pemain Pro Game Online
}

\author{
Nur Azizah Jamal ${ }^{1}$, Rini Sugiarti ${ }^{2}$ \\ ${ }^{1,2}$ Magister Psikologi, Universitas Semarang \\ Jl. Soekarno Hatta, Tlogosari Kulon, Pedurungan, Kota Semarang, Jawa Tengah 59160 \\ e-mail: nurazizahjamal7@gmail.com ${ }^{1}$, rinisugiartipsikologi@usm.ac.id ${ }^{2}$
}

Article History:

Received

22 April 2021

Review

10 Mei 2021

Revised

19 Mei 2021

Accepted

9 Juni 2021

Published

23 Juni 2021

Reviewer A:

Fendy Suhariadi
Abstract. This study aims to determine the effect of self-control on aggressiveness in young online game players. The population in this study was pro online game players in $X$ city with a total of 103 subjects through incidental sampling. The measuring instrument used consists of 2 scales, namely an aggressiveness scale consisting of 32 items and a self-control scale consisting of 48 items. The alpha cronbach reliability coefficient on the aggressiveness variable was $\alpha=0.775$, while the alpha cronbach value reliability coefficient on the self-control variable was $\alpha=0.900$. Data analysis using PLS (Partial Least Square). The results of the correlation test showed that there was an effect of selfcontrol on aggressiveness, the regression coefficient $(\beta)=-0.60$ and $p$ value $=<0.01$. This shows a significant influence between self-control on aggressiveness.

Keywords: Self Control, Aggressiveness, Online Game.

Abstrak. Penelitian ini bertujuan untuk mengetahui pengaruh antara kontrol diri terhadap agresivitas pada remaja pemain game online. Populasi dalam penelitian ini pemain pro game online yang terdapat di kota X dengan total 103 subjek melalui incidental sampling. Alat ukur yang digunakan terdiri dari 2 skala yaitu skala agresivitas yang terdiri 32 aitem dan skala kontrol diri yang terdiri atas 48 aitem. Koefisien reliabilitas alpha cronbach pada variabel agresivitas sebesar $\alpha=0.775$, sedangkan koefisien reliabilitas nilai alpha cronbach pada variabel kontrol diri sebesar $\alpha=0.900$. Analisis data menggunakan PLS (Partial least square). Hasil uji korelasi menunjukkan ada pengaruh kontrol diri terhadap agresivitas, Koefisien Regresi $(\beta)=-0.60$ dan $p$-value $=<0.01$. Hal ini menunjukkan pengaruh yang signifikan antara kontrol diri terhadap agresivitas.

Kata kunci: Kontrol Diri, Agresivitas, Game Online

\section{Pendahuluan}

Remaja merupakan masa pencarian jati diri yang dialami oleh seseorang, serta munculnya perubahan baik secara fisik ataupun psikis (Papalia, Old, \& Feldman, 2009). Remaja madya umumnya menempuh bangku sekolah menengah atas. Masa remaja dipengaruhi oleh dua faktor dalam membentuk karakter diantaranya adalah pola asuh orang tua serta lingkungan yang terdiri dari pertemanan atau kawan bermain (Hurlock, 2011). Santrock (2011) menjelaskan bahwa remaja merupakan masa perkembangan transisi antara masa kanak-kanak dan masa dewasa yang mencakup perubahan biologis, 
kognitif, dan sosial emosional. Rentan usia remaja dibedakan atas tiga yaitu: remaja awal 12-15 tahun, remaja madya 15-18 tahun, remaja akhir 18-21 tahun (Santrock, 2011).

Baron dan Byrne (2003) menjelaskan bahwa munculnya agresivitas pada remaja dipengaruhi oleh faktor yang diantara terdiri atas faktor biologis yaitu kematangan emosi, faktor eksternal terdiri atas lingkungan, faktor belajar terdiri atas lingkungan dan pertemanan. Social learning theory menyebutkan bahwa agresivitas yang muncul dari seseorang merupakan suatu suatu proses pembelajaran yang melibatkan adanya interaksi antar individu dan lingkungan. Bandura (2014) juga menjelaskan bahwa individu melakukan pembelajaran melalui pengamatan dan meniru yang ada di sekitarnya sehingga akan menjadi perilaku model atau perilaku contoh dan apabila perilaku ini memperoleh penguatan maka akan menjadi perilaku dirinya. Seseorang melakukan agresivitas karena timbulnya dorongan dari dalam diri individu secara biologis dan aspek emosional yang muncul sehingga membuat seseorang untuk melakukan agresif (Mu'arifah, 2005). Remaja menyukai game online, hal ini terlihat dari data statistik pengguna game online di Indonesia berjumlah 43,7 juta jiwa (Lokadata, 2017). Game online dapat memunculkan agresivitas, baik secara verbal seperti mengumpat, berkata kasar, ataupun non verbal seperti memukul, mengganggu, dan menyerang orang lain (Toda \& Oh, 2016).

Dampak negatif yang ditimbulkan diantaranya adalah badan lemas karena kurang istirahat, kurang tidur, badan lemas, dan lain-lain (Fahd, 2015). Game Online merupakan permainan yang melibatkan aktivitas bermain dimana didalamnya ikut terlibat pada konteks berpura-pura akan tetapi terlihat realitas yang mana pemainnya memiliki tujuan agar memperoleh kemenangan serta dilakukan sesuai dengan aturan pada permainan tersebut yang terdiri: Action Game, Strategy Game, Role-Playing Game, Real-world Stimulation, Construction and management games, Adventure Games, Puzzle Games (Adam, 2006). Game online merupakan sebuah aplikasi dimana dipakai pada media elektronik dengan tujuan untuk memperoleh kesenangan dan kemenangan (Sibero, 2012). Hendry (2010) mengatakan bahwa game online merupakan salah satu bagian yang tidak dapat dipisahkan pada setiap orang terutama pada anak-anak. Pendapat lain dikemukakan oleh Naisbith (2015) game online merupakan sebuah system partisipatoris karena memiliki tingkat kesulitan dan bercerita disetiap sesi permainan untuk memperoleh kemenangan. Game online adalah permainan yang dapat diakses oleh banyak pemain, di mana mesinmesin yang digunakan pemain dihubungkan oleh internet (Rupita, 2016). 
Bandura (Hill, 2014) menjelaskan bahwa tahap pembelajaran secara langsung diamati dengan lingkungan sekitar, hal ini akan membuat munculnya agresi baik secara fisik ataupun verbal. Seseorang berperilaku agresif saat bermain game online disebabkan oleh berbagai faktor, diantaranya adalah pola pertemanan dan lingkungan (Hill, 2014). Seseorang menyukai game karena pola kebiasaan melihat dari lingkungan dan teman. Teori belajar sosial yang menekankan bahwa lingkungan berpengaruh besar dalam pembentukan perilaku seseorang secarakebetulan ataupun tidak sadar, yang mana menyebabkan dipilih dan kerap diubah sesuai dengan perilakunya sendiri (Apriyanti \& Hermanto, 2015). Restu \&Yusri (2013) menyebutkan bahwa faktor-faktor seseorang berperilaku agresif yaitu frustrasi, kekuasaan, provokasi, dan suhu udara. Berbagai jenis game online seperti Mobile Legends yang ada saat ini dapat memberikan dampak negatif penggunanya. Tanjung (2015) menjelaskan dampak negatif yang ditimbulkan dari game online adalah waktu yang terbuang sia-sia serta terganggunya interaksi sosial seseorang. Dampak negatif yang juga ditimbulkan dari game online yaitu: membuat seseorang malas melakukan aktivitas serta menjadikan waktu luang hanya untuk bermain game online, mengabiskan waktu luang serta melalaikan kegiatan harian untuk bermain game online, belajar dan membantu orang tua menjadi terbengkalai ketika pulang dari sekolah karena bermain game, lupa akan waktu, pola makan terganggu, emosional yang berubah-ubah karena efek dari game ini, waktu beribadah akan sering dilalaikan, membuat seseorang akan membolos demi game kesukaan, berperilaku kasar, membantah, serta melawan orang tua, membuat seseorang berbohong (Akmarina, 2016).

Faktor-faktor yang menjadi penyebab munculnya agresivitas menurut Firdaus, Muhari, Christiana \& Pratiwi (2014) diantaranya yaitu: perhatian yang kurang diperoleh dari orang tua, masih dalam tahap perkembangan, pengaruh teman sebaya, adanya proses imitasi dari perilaku teman, keluarga yang kurang harmonis, solidaritas yang tinggi dalam berteman, perasaan salah paham antar teman, konflik internal keluarga, munculnya perasaan tersinggung, emosi, jengkel, sakit hati, keinginan untuk menjaga harga diri, keinginan untuk coba-coba, munculnya keinginan untuk meluapkan emosi, pergaulan salah, kurang senang melihat orang lain yang memiliki sikap sombong dan angkuh, kurangnya pembinaan dari orang tua.

Kematangan emosi menurut Muamanah, Suroso \& Pratikto (2012) adalah kemampuan untuk menampilkan emosi yang tepat dalam pengendalian diri, mandiri, ada konsekuensi diri, serta penerimaan terhadap diri sendiri. Kematangan emosi adalah perasaan atau keyakinan yang dapat menilai situasi secara kritis sebelum bertindak serta 
memiliki kontrol emosi yang baik ketika menyampaikan sesuatu (2017). Syarif (2017) juga menambahkan bahwa kematangan emosi menjadi dasar untuk bersikap toleran, mampu mengontrol diri sendiri, perasaan untuk menerima, serta menyampaikan emosi secara konstruktif dan kreatif. Chaplin (2011) juga mengatakan bahwa kematangan emosi merupakan suatu tingkat kedewasaan berdasarkan perkembangan emosi untuk diperlihatkan kepada orang lain secara pantas. Young (Syarif, 2017) faktor-faktor yang mempengaruhi kematangan emosi, diantaranya: lingkungan menjadi tempat melakukan interaksi seperti didalam keluarga atau di masyarakat, faktor internal karena ini berasal dari dalam diri seseorang untuk bisa menahan gejolak emosi yang ingin tersalurkan, dan pengalaman yang telah dilalui.

Tujuan dari penelitian ini adalah untuk menguji secara empiris kontrol diri terhadap agresivitas melalui pada remaja pemain game online.

\section{Metode}

Variabel-variabel yang diajukan dalam penelitian ini diantaranya sebagai berikut: Agresivitas (Y), Kontrol Diri (X1). Populasi dalam penelitian ini adalah pemain pro gamers di Kota X. Karakteristik dari penelitian yang akan dilakukan adalah pemain pro game online berjenis kelamin laki-laki. Jumlah subjek dalam penelitian ini sebanyak 103 orang. Teknik pengambilan sampel pada penelitian ini adalah sampling insidental. Metode pengumpulan data yang digunakan dalam penelitian ini menggunakan skala, Peneliti memakai skala agresifitas, skala kontrol. Uji validitas yang digunakan pada penelitian ini yaitu validitas isi (content validity). Penelitian ini menggunaan uji daya beda alpha cronbach. Metode analisis data pada penelitian ini dengan menggunakan PLS (Partial Least Squares).

\section{Hasil}

Uji validitas dan reliabilitas alat ukur yang digunakan pada skala agresivitas terhadap 32 aitem yang menggunakkan teknik Alpha Cronbach diperoleh koefisien reliabilitas alpha sebesar 0,775 . Uji daya beda aitem yang dilakukan pada total 32 aitem diperoleh 14 aitem yang valid dan 18 aitem yang tidak valid. uji validitas reliabilitas alat ukur yang digunakan pada skala kontrol diri terhadap 48 aitem yang menggunakkan teknik Alpha Cronbach diperoleh koefisien realibilitas alpha sebesar 0,900. Uji daya beda aitem yang dilakukan pada total 48 aitem diperoleh 35 aitem yang valid dan 13 aitem yang tidak valid. Berdasarkan hasil pengelolaan data, hasil table effect size adalah sebagai berikut: 
Philanthropy Journal of Psychology

Vol 5 Nomor 1 (2021), 47-58

ISSN 2580-6076 (Print), ISSN 2580-8532 (Online)

Tabel 1. Direct Effect

\begin{tabular}{c|l|c|c}
\hline Kriteria & \multicolumn{1}{|c|}{ Variabel } & Y & X1 \\
\hline \multirow{2}{*}{ Path Coeficients } & Y Agresivitas & & -0.562 \\
\cline { 2 - 4 } & X1 Kontrol Diri & & \\
\hline
\end{tabular}

\begin{tabular}{c|l|c|c}
\hline Kriteria & \multicolumn{1}{|c|}{ Variabel } & Y & X1 \\
\hline \multirow{2}{*}{$\boldsymbol{P}$ - Value } & Y Agresivitas & & $<0.001$ \\
\cline { 2 - 4 } & X1 Kontrol Diri & & \\
\hline
\end{tabular}

\begin{tabular}{c|l|c|c}
\hline Kriteria & \multicolumn{1}{|c|}{ Variabel } & Y & X1 \\
\hline $\begin{array}{c}\text { Effect sizes for } \\
\text { path coefficients }\end{array}$ & Y Agresivitas & & 0.368 \\
\cline { 2 - 4 } & X1 Kontrol Diri & & \\
\hline
\end{tabular}

Sumber: Data primer yang diolah, 2020

Berdasarkan hasil pengelahan data, hasil gambar pengolahan data penelitian dari effect size adalah sebagai berikut:

\section{Gambar 1. Hasil Penelitian}

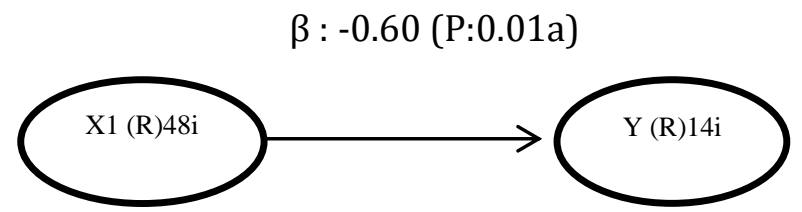

\begin{tabular}{c|c|c|c}
\hline \multicolumn{1}{c|}{ Hipotesis } & $\begin{array}{c}\text { Koefisien } \\
\text { Regresi }(\boldsymbol{\beta})\end{array}$ & P - Value & Hasil \\
\hline $\begin{array}{l}\text { Ada pengaruh antara kontrol } \\
\text { diri terhadap agresivitas }\end{array}$ & -0.60 & $<0.01$ & Diterima \\
\hline
\end{tabular}

Keterangan:

$X$ : Kontrol Diri

Y : Agresivitas

Berdasarkan hasil uji analisis data diperoleh hasil:

Hipotesis 1 diterima, artinya kontrol diri berpengaruh negatif dengan memiliki nilai koefisien regresi $(\beta)-0.60$ dan sangat signifikan terhadap agresivitas dengan nilai Pvalue 0.01 yang artinya $<0.01$.

\section{Diskusi}

Berdasarkan hasil penelitian hipotesis 1, adanya pengaruh negatif antara kontrol terhadap agresivitas serta memiliki nilai signifikansi 0.01 sehingga hipotesis yang diajukan peneliti dapat diterima. Nilai beta $(\beta)$ sebesar -0.60 dan nilai sangat signifikan 0.01. yaitu sama besar dengan nilai 0.01 . Nilai $\mathrm{R}^{2}$ dapat dilihat pada effect size. Hasil tersebut menunjukkan bahwa hipotesis pertama memiliki cukup bukti untuk diterima. 
Hasil ini selaras dengan penelitian terdahulu yang dilakukan oleh Ismail dan Sugiarti (2019) bahwa ada hubungan negatif searah antara kontrol diri dengan agresivitas, semakin tinggi kontrol diri semakin rendah pula tingkat agresivitas. Zahri dan Savira (2017) serta Karim (2019) yang mana dalam penelitian tersebut menunjukkan bahwa kontrol diri dapat mengubah perilaku agresif, artinya semakin baik kontrol diri maka semakin rendah pula agresivitas seseorang. Ubaidillah (2017) menjelaskan kontrol diri yang tinggi dapat mengurangi tindak agresif seseorang.

Temuan ini sejalan dengan teori psikologi sosial yang menunjukkan adanya kontrol diri dapat mempengaruhi agresivitas. Dalam hal ini kontrol diri merupakan tindakan berkaitan dengan bagaimana individu mengendalikan emosi serta dorongan-dorongan dalam dirinya. Jika seseorang memiliki kontrol diri yang baik, maka akan mengurangi munculnya perilaku agresivitas seseorang (Fromm, 2000). Agresivitas merupakan dorongan dari dalam seseorang untuk melukai orang lain baik secara sengaja ataupun tidak sengaja dengan berusaha menyakiti fisik ataupun non fisik (Stangor, Jhangiani, Tarry, 2011). Baron \& Byrne (2003) menjelaskan bahwa agresivitas merupakan sebuah tindakan yang mana didalamnya memiliki tujuan untuk melukai atau mencelakai orang lain yang tidak mengharapkan datangnya tingkah laku tersebut.

Berdasarkan hasil penelitian yang telah dilakukan oleh peneliti, dikaitkan dengan kajian teori serta penelitian terdahulu maka di simpulkan bahwa kontrol diri dapat mempengaruhi agresivitas. Semakin baik kontrol diri yang dimiliki seseorang, maka semakin rendah pula untuk munculnya perilaku agresivitas.

\section{Simpulan}

Berdasarkan hasil penelitian yang telah dilakukan maka diketahui bahwa penelitian ini menggunakan analisis korelasi berganda PLS (Partial Least Square) berbasis SEM. Kesimpulan yang diperoleh diantaranya:

H1: Ada Pengaruh antara Kontrol diri terhadap agresivitas. Koefisien regresi $(\beta)-0.58$ dan signifikansi 0.01 (sangat signifikan).

\section{Saran}

Beberapa saran yang dapat peneliti paparkan berdasarkan penelitian yang telah dilakukan, diantaranya:

\section{Bagi pemain pro game online}

Penelitian ini diharapkan dapat menjelaskan bahwa kontrol diri, dukungan sosial teman sebaya, serta kematangan emosi menjadi salah satu faktor munculnya perilaku 
agresivitas seseorang. Koefisien determinasi $\left(\mathrm{R}^{2}\right)$ pada agresivitas 0.54 atau $54 \%$ dan kematangan emosi sebesar 0.62 atau 62\% sehingga dapat dilihat bahwa bahwa agresivitas dan kematangan emosi memberikan sumbangan pengaruh yang cukup tinggi. Kontrol diri yang baik dapat menyebabkan rendahnya perilaku agresivitas. Kontrol diri yang baik dapat menunjukkan tingginya kematangan emosi. Dukungan sosial teman sebaya yang tinggi menunjukkan kematangan emosi. Kematangan emosi yang baik dapat menurunkan perilaku agresivitas seseorang.

\section{Bagi peneliti selanjutnya}

Bagi peneliti selanjutnya diharapkan agar dalam melakukan penelitian akan lebih memiliki banyak acuan teori juga menggali lebih mendalam faktor-faktor lain yang mempengaruhi agresivitas. Selain itu diharapkan memperluas cakupan subjek penelitian yang akan di teliti selanjutnya.

\section{Kepustakaan}

Adam, E. (2006). Dalam K. Johnson (Penyunt.), Fundamental of game design (3rd ed.). Peachpit Press.

Adlya, S. I., Yusuf, M. Z., \& Effendi, M. (2020). The contribution of self control to students' discipline. Journal of Counseling and Educational Technology, 3, 1-5.

Adyani , L., Suzanna , E., Safuwan, \& Mulyali . (2018). Perceived social support and psychological wellbeing among interstate students at Malikussaleh University. Jurnal Indigenous, 3, 98-104.

Afiah, N. (2015, Juni). Kepribadian dan Agresivitas dalam berbagai budaya. Journal Buletin Psikologi, 23, 13-21.

Agustina, I., Syahniar, \& Karneli , Y. (2019). Relationship of Emotional Maturity with Student Aggressive Behavior. Jurnal Neo Konseling, 1, 1-6.

Akmarina, Y. N. (2016). Pengaruh bermain game online terhadap efektiitas berkomunikasi dalam keluarga di Kelurahan Swarga Bara Kota Sangatta Kab. Kutai Timur. Ejournal Ilmu Komunikasi Fisip Universitas Mulawarman , 4, 189-199.

Albin, R. S. (2002). Emosi: Bagaimana Mengenal dan Mengarahkan . Yogyakarta: Kanisius.

Amanda, A. N., \& Tobing, D. (2017). Hubungan konformitas dan kecerdasan emosi terhadap agresivitas pada remaja madya di SMAN 7 Denpasar. Jurnal Psikologi Udayana, 4, 92-101.

Amanda, R. A. (2016). Pengaruh game online terhadap perubahan perilaku agresif remaja di Samarinda. Ejournal Ilmu Komunikasi , 4, 290-304.

Anderson, C. A., \& Huesmann, L. R. (2007). Human Aggression. A Social Cognitif View, 21, 297-323. 
Annisavitry, Y., \& Budiani, S. M. (2017). Hubungan antara Kematangan Emosi dengan Agresivitas pada Remaja. Jurnal Psikologi Pendidikan , 4, 1-6.

Apriyanti, M. F., \& Hermanto. (2015). Perilaku agresif remaja yang gemar bermain game online. Kajian Moral dan Kewarganegaraan , 03, 994-1008.

Asmadi, A. (2003). Pendekatan Kuatitatif Kualitatif serta Kombinasinya dalam Penelitian Psikologi (1 ed.). YogyakartaPustaka Pelajar.

Asmoro, A. R., Matulessy, A., \& Meiyutariningsih, T. (2018). Kematangan Emosi, Kontrol Diri, dan Perilaku Agresi Pada Anggota Korps Brigade Mobil Dalam Menangani Huru Hara. Jurnal Psikologi Teori dan Terapan , 9, 39-48.

Aviyah, E., \& Farid , M. (2014). Religiusitas, Kontrol Diri Dan Kenakalan Remaja. Persona, Jurnal Psikologi Indonesia, 3, 126-129.

Azwar, S. (2012). Metode Penelitian. Yogyakarta: Pustaka Belajar.

Babaroglu , A. (2016). Aggression Behaviors in Children with and without Hearing Impairment. International Journal of Psychological Studies, 8, 14-27.

Baron, R. A., \& Byrne, D. (2003). Social Psychology (10 ed.). (R. M. Wisnu Cristiaji, Penyunt.) Erlangga.

Berlkowitz. (2003). Emotional Behavior: Mengenal perilaku dan tindakan kekerasan di Lingkungan sekitar kita dan cara penanggulangannya (4 ed.). Jakarta: Penerbit PPM.

Bhochhibhoya , A., Dong, Y., \& Branscum, P. (2017). Sources of Social Support Among International College Students in the United States. Journal of International Students, 7, 671-686.

Budikuncoroningsih, S. (2017, September). Pengaruh teman sebaya dan persepsi pola asuh orang tua terhadap agresivitas siswa di sekolah dasar gugus Sugarda. Jurnal Sains dan Humaniora , 1, 85-92.

Chaplin, J. P. (2011). Kamus Lengkap Psikologi. (Kartini, \& Kartono, Penerj.) Jakarta: Raja Grafindo Perkasa.

Corsini, J. R. (2002). Dalam Dictionary of Psychology. Great Britain: Brunner-Routledge.

Cowie, H., \& Wallace, P. (2000). Dalam Peer Support in Action: From Bystanding to Standing. London : Sage Publications.

Damayanti, N., \& Ilyas, A. (2018). Self-control profile of students in implementing discipline in school. Jurnal Penelitian Guru Indonesia, 3, 103-109.

Dalton, James , H., Ellias, J. M., \& Wandersman, A. (2007). Dalam Community Psychology:Linking Individuals and Communities. USA: Thomson Wadsworth.

Dayakisni, T., \& Hudaniah. (2009). Psikologi Sosial (4 ed.). Malang: UMM Pres.

Desiningrum, D. R. (2014). Keseahteraan Psikologis Lansia Janda/Duda Ditinjau dari Persepsi Terhadap Dukungan Sosial dan Gender. Jurnal Psikologi Undip , 13, 102106. 
Dewi, R. W., \& Savira, I. S. (2017). Kecerdasan Emosi dan Perilaku Agresi di Social Media pada remaja. Jurnal Psikologi Teori dan Terapan , 7, 82-87.

Dimatteo, M. R. (2004). Social support and patient adherence to medical treatment : a meta analysis. Health Psychology Journal, 2, 207-218.

Firdaus, M. T., Muhari, Christiana, E., \& Pratiwi, T. I. (2014). Faktor-faktor penyebab perilaku agresif pada siswa di SMP kelurahan Kedung Asem Surabaya. Jurnal BK Unesa, 1, 68-76.

Fromm, E. (2000). The Anatomy of Human Destructiviness (1 ed.). (Kamdani, Penyunt., \& I. Muttaqin, Penerj.) Yogyakarta: Pustaka Pelajar.

Ghozali, I. (2014). Dalam Partial Least Squares ( Konsep, Metode, dan Aplikasi). Semarang: Universitas Diponegoro.

Ghozali, I. (2016). Dalam Aplikasi Analisis Multivariete Dengan Program IBM SPSS 23. Semarang: Universitas Diponegoro.

Ghozali, I. (2008). Dalam Structural Equation Modelling. Semarang. Universitas Diponegoro

Ghufron, M. N., \& Risnawati, R. (2010). Dalam Teori-Teori Psikologi. Yogyakarta: Ar-Ruzz Media.

Ghustara. (2018). Game android multiplayer. Diambil kembali dari https://www.vagaming.com

Gong, Y., Rai, D., Beck, J. E., \& Heffernan, N. T. (2009). .Does Self-Discipline impact students' knowledge and learning? Educational Data Mining, 61-70.

Guswani, A. M., \& Kawuryan, F. (2011). Perilaku agresi pada mahasiswa ditinjau dari kematangan emosi. Jurnal Psikologi Pitutur, 1, 86-92.

Hadi, S. (2001). Metodologi Research. Yogyakarta: Andi Offset.

Harahap, J. Y. (2017). Hubungan antara Kontrol Diri dengan Ketergantungan Internet di Pustaka Digital Perpustakaan Daerah Medan. Jurnal Edukasi , 3, 131-145.

Hastuti , L. W. (2018). Buletin Psikologi. Kontrol Diri dan Agresi: Tinjauan Meta-Analisis, 26, 42-53.

Hendry, S. (2010). Cerdas dengan Game. Indonesia: Gramedia Pustaka Utama.

Hidayat, N., \& Nurhayati , S. R. (2019). The Effect O Support And Hope On Resilience in Adolescents. Humaniora , 10, 219-225.

Hidayat, A. (2012, September 1). Uji Normalitas Dengan Kolmogorov Smirnov. Diambil kembali dari www.statistikian.com: http://www.statistikian.com/2012/09/ujinormalitas-dengan-kolmogorov-smirnov.html

Hidayat, A. (2013, Maret 1). Linearitas Regresi. Diambil kembali dari www.statistikian.com: http://www.statistikian.com/2013/03/linearitasregresi.html

Hill, W. F. (2014). Theories Of Learning. Bandung: Nusa Media. 
Philanthropy Journal of Psychology

Vol 5 Nomor 1 (2021), 47-58

ISSN 2580-6076 (Print), ISSN 2580-8532 (Online)

Hurlock. (2011). Developmental Psychology. (D. R. Sijabat, Penyunt.) Erlangga.

Intani, C. P., \& Ifdil, I. (2018). Hubungan kontrol diri dengan prestasi belajar siswa. Jurnal Pendidikan Indonesia, 4, 65-70.

Ismail , A. B., \& Zawahreh , N. (2017). Self-control and its Relationship with the Internet Addiction among a Sample ofNajran University Students. Journal of Education and Human Development, 6, 168-174.

Istiqomah. (2017, Oktober). Penggunaan media sosial dengan tingkat agresivitas remaja. Jurnal Insight Fakultas Psikologi Universitas Muhammadiyah Jember, 13, 96-111.

Janah , M. R., Rifayani , H., \& Sri Ernawati , S. (2017). Emotion RegulationTo Reducing Aggressive Behavior In Resolving Interpersonal Conflict On Student SMK. Jurnal Pemikiran Administrasi Publik dan Bisnis, Sosial dan Politik, 9, 56-62.

Jiméneza , T., \& Estévez, E. (2017). School aggression in adolescence: Examining the role of individual, family and school variables. International Journal of Clinical and Health Psychology ., 17, 251-260.

Joy , M., \& Mathew , A. (2018). Emotional Maturity and General WellBeing of Adolescents. IOSR Journal Of Pharmacy www.iosrphr.org , 8, 1-6.

Jung, J., Krahe, B., \& Busching, R. (2018). Beyond the positive reinforcement of aggression: Peers' acceptance of aggression promotes aggression via external control beliefs. International Journal of Behavior.

Kaur , P. (2019). Study of emotional maturity of adolescents in relation to their adjustment. International Journal of Advanced Education and Research, 4, 21-25.

Kartono , R. (2000). Dalam Kamus Psikologi . Bandung: Pionir Jaya.

King, L.A. (2012). Psikologi Umum : Sebuah Pandangan Apresiatif Buku 2. Jakarta: Salemba Humanika.

Koeswara, E. (2001). Teori Kepribadian. Bandung: PT Erasco.

Kominfo. (2014). Kementrian komunikasi dan informatika. Diambil kembali dari Pengguna internet indonesia: http://kominfo.go.id

Krahe, B. (2005). Buku panduan psikologi sosial : Perilaku agresi. Yogyakarta: Pustaka Pelajar Offset.

Maisaroh, D., Dharmayana, W., \& Afriyati, V. (2016). Pengaru Latihan Self Control Melalui Konseling Kelompok Terhadap Kecenderungan Agresif Siswa. Triadik, 15, 79-90.

Marhamah, F., \& Hamzah, H. b. (2016). The Relationship Between Social Support And Academic Stress Among First Year Students At Syiah Kuala University. Jurnal Psikoislamedia, 1, 149-172.

Maagerø-Bangstad, E., Sælør, K., \& Ness , O. (2019). Encountering staff-directed aggression within mental health and substance abuse services: exploring conceptions of practice following education. International Journal ofMental Health Systems, 13, 113. 
Maharani, P., \& Laksmiwati, H. (2017). Kematangan emosi dan religiusitas terhadap kecenderungan agresi pada siswa. Jurnal psikologi teori dan terapan, 8, 33-42.

Margono. (2010). Dalam Metodologi Penelitian Pendidikan. Jakarta: Rineka Cipta.

Marni, A., \& Yuniawati, R. (2015). Huibungan Antara Dukungan Sosial Dengan Penerimaan Diri Pada Lansia Di Panti Wredha Budhi Dharma Yogyakarta. Jurnal Fakultas Psikologi, 3, 1-7.

Marsela, R. D., \& Supriatna, M. (2019). Kontrol Diri : Definisi dan Faktor. Journal of Innovative Counseling : Theory, Practice \& Research, 3, 65-69.

Muamanah, L. B., Suroso, \& Pratikto, H. (2012). Kematangan Emosi, Konsep, dan Kenakalan Remaja. Jurnal Psikologi Persona, 19, 490-500.

Mu'arifah. (2005, Agustus 2). Hubungan kecemasan dan agresivitas . Humanitas: Indonesia Psychological Journal, 2, 102-111.

Muawanah, L. B., Suroso, \& Pratikto. (2012). Kematangan emosi, konsep diri, dan kenakalan remaja. Jurnal Persona, 1, 1-9.

Muhammad, M., Nirwana , H., \& Marjohan . (2019). International Journal of Applied Counseling and Social Sciences. Social Support for Adolescent Resilience Conflicts in Divorced Parents, 1, 34-39.

Myers, D. (2010). Social Psychology (10 ed.). New York, United States of America: McGraw-Hill Book Company.

Naisbitt. (2015). Global Game Change: How the Global Southern Belt will Reshape Our World (1st ed.). (Megantrends, Penyunt.) Canada: Sage Publication.

Notoatmojo, S. (2010). Metodologi Penelitian Kesehatan. Bandung: Rineka Cipta.

Nurtjahyo, Matulessy. (2013, September). Hubungan kematangan emosi dan konformitas terhadap agresivitas verbal. Persona, Jurnal Psikologi Indonesia, 2, 223-231.

Papalia \& Fieldman. (2014). (Masyukur, Penyunt., \& Herarti, Penerj.) Jakarta: Salemba Humanika.

Papalia, D. E., Old, W. S., \& Feldman, D. R. (2009). Human Development (10 ed.). (Widyaningrum, Penyunt., \& Marwensdy, Penerj.) Salemba Humanika.

Patty, S., Wijono, S., \& Setiawan, A. (2016). Hubungan Dukungan Sosial Teman Sebaya, Kontrol Diri, dan Jenis Kelamin dengan Prestasi Belajarsiswa di SMA Kristen YPKPM Ambon. Psikodimensia , 15, 204-235.

Purnama, D. S. (2006). Upaya guru dalam mengembangkan disiplin belajar siswa. Paradigma, 101-109.

Rajeshwari , R. R., \& Raj , J. M. (2017). A Study On Relationship Between Emotional Maturity, Stress, and Self Confidence Among Management Students. Asia Pacific Journal of Research, 1, 95-99. 
Ramadhani , R. A., \& Fakhrurrozi , M. (2019). Social Support and How It Affects Fear of Success among Female Police Officers in Jakarta. International Journal of Research Publications, 23.

Reksoatmodjo, T. N. (2009). Statistik untuk Psikologi dan Pendidikan. Bandung: Rafika Aditama.

Restu, Y., \& Yusri. (2013). Studi tentang perilaku agresif siswa di sekolah. Jurnal Ilmiah Konseling, 2, 243-249.

Reyna , C., Ivacevich , M. L., Sanchez , A., \& Brussino , S. (2015). The Buss-Perry Aggression The Buss Perry Questionnaire: Construct validity and gender in variance among Argentinean adolescents. International Journal of Psychological Research, 4, 3037.

Ridyawanti. (2007). Hubungan identitas sosial dan konformitas kelompok dengan agresivitas pada suporter sepakbola persija. ejurnal Psikologi, 2, 241-253.

Rogers, D. (1981). Adolescents and Youth. New York: Pretince Hall.

Santrock, J. W. (2011). Life-Span Development (13 ed.). (Sallama, Penyunt., \& Widyasinta, Penerj.) Erlangga.

Sarafino, E. P., \& Smith. (2011). Dalam Health Psychology: Biopsychosocial interaction (7 ed.). New Jersey: Jhon Willey \& Sons .

Sarwono, S. (1998). Teori-teori psikologi sosial. Jakarta: PT. Grafindo Persada.

Sarwono, S.W., \& Meinarno, E.A. (2009) Psikologi Sosial. Jakarta: Salemba Humanika Schneiders, A. A. (1960). Personal Adjusment and Mental Health ebook.

Sears, D. O., Taylor, S. E., \& Peplau, L. A. (2004). Social Psychology (5 ed.). (M. Adryanto, Penyunt.) Erlangga.

Sentana, M. A. (2017). Agresivitas dan Kontrol Diri pada Remaja di Banda Aceh, 51-55.

Sibero. (2012). Membuat Game 2D Menggunakan Game Maker. Yogyakarta: Mediakom.

Siddiqiah, L. (2010, Juni). Pencegahan dan penanganan perilaku agresif remaja melalui pengelolaan amarah (Anger Management). Jurnal Psikologi , 37, 50-64.

Siegel, S. (2011). Dalam Statistik Nonparametrik Untuk Ilmu-Ilmu Sosial. Jakarta: Gramedia.

Sirikulchayanonta, C., Ratanopas, W., Temcharoen, P., \& Srisorrachatr. (2011). Self discipline and obesity in Bangkok school Children. BMC Public Health, 11, 1-8.

Stangor, J. \&. (2012). Principles of Social Psychology (1st ed.). British: Psychlogical Press Book.

Stangor, Jhangiani, Tarry. (2011). Principles of Social Psychology (Vol. 21). British Britain: https://archive.org/stream/PrincipleOfSocialPsychology.

Sugiarti, R. (2019). Karakteristik Cerdas Istimewa. Banyumas: CV. Pena Persada Sugiyono. (2009). Metode Penelitian Kuantitatif dan Kualitatif R\&D. Bandung: Alfabeta. 
Philanthropy Journal of Psychology

Vol 5 Nomor 1 (2021), 47-58

ISSN 2580-6076 (Print), ISSN 2580-8532 (Online)

Sugiyono. (2012). Metode Penelitian Administrasi. (Cetakan Ke-20 ed.). Bandung: Alfabeta.

Sugiyono. (2015). Metode Penelitian "Kuantitatif, Kualitatif dan R\&D". Bandung: CV.Alfabeta.

Supriyanto, E. (2017). Hubungan antara kematangan emosi dan agresivitas pada pemain sepak bola remaja akhir. Jurnal Psikologi, 1, 182-191.

Syahran, R. (2015). Ketergantungan online game dan penanganannya . Jurnal Psikologi Pendidikan dan Konseling, 1, 84-92.

Syarif, F. (2017). Hubungan kematangan emosi dengan perilaku agresi pada mahasiswa warga asrama komplek asrama ayu sampaja. ejournal psikologi fisip unmul, 5.

Syarif, F. (2017). Hubungan kematangan emosi dengan perilaku agresi pada mahasiswa warga asrama komplek asrama ayu sampaja. Jurnal Psikoborneo, 5, 267-280.

Tanjung, V. P. (2015, September). Game online dan Agresivitas anak usia SMP di Sidoarjo . Kanal, 4, 63-80.

Tausikal, R. F. (2008). Hubungan antara intensitas komunikasi interpersonal dengan agresivitas. Psikologika, 13, 73-82.

Taylor, S. (2015). Dalam Health Psychology. New York: McGraw-Hill Education.

Temtama, F. (2012). Perilaku anak agresif: Asesmen dan Intervensinya. Kesmas, 6, 162232.

Titisari, H. T. (2017). Hubungan antara Penyesuaian diri dan Kontrol diri dengan Perilaku Delikuen pada siswa SMA Muhammadiah Jombang. Psikodimensia, 16, 132-140.

Toda , Y., \& Oh , I. (2016). International Journal Of Psychology. Aggression and Prosocial Behavior, 15-30.

Ulfa, M. (2017). Pengaruh kecanduan game online terhadap perilaku remaja di mabes game center jalan HR. Subrantas kecamatan Tampan kabupaten Riau. Jurnal Mahasiswa Fisip Universitas Riau, 4, 1-13.

Utami, A. F., \& Sumaryono. (2008). Pembelian Impulsif dari Kontrol Diri dan Jenis Kelamin pada Remaja. Jurnal Psikologi Proyeksi, 1, 46-57.

Walgito, B. (2004). Psikologi sosial suatu pengantar. Yogyakarta: Andi.

Wani1, M., \& Masih , A. (2015). Emotional Maturity across Gender and Level of Education. The International Journal of Indian Psychology, 2, 63-74.

Watson, D. L., Tregerthan, G. D., \& Frank, J. (2006). Social Psychology. United States of Amerika, United States of Amerika: Library of Congress Cataloging n Publication data.

Whitwham , S., \& Jones , K. (2019). Brain Injury. Assessing aggression following Acquired Brain Injury (ABI): a systematic review of assessment measures, 33, 1491-1502. 
ISSN 2580-6076 (Print), ISSN 2580-8532 (Online)

Wibowo, A. (2017, Februari 2). Tips Pemula Mobile Legends: Cara cepat naik rank dari Warrior menjadi Grand Master. hhtp://www.duniaku.net/2017/06/02/tipspemula-mobile-legends-naik-rank/.

Yufiarti, Qorina, \& Sitorus , A. (2018). International Journal of Engineering \& Technology. Intensity Differences in Playing Online Games Against Child Aggression, 7, 109-111.

Yusuf, S. (2009). Mental Hygiene: Pengembangan Kesehatan mental dalam kajian psikologi dan agama. Bandung: Pustaka Bani Quraisy.

Zamzani, A. (2007). Jurnal Pendidikan dan Kebudayaan. Agresivitas Siswa SMK DKI Jakarta, 4, 942-965. 